\title{
A TESZTFELVÉTEL IDÓTARTAMÁNAK HATÁSA A KREATIVITÁSTESZTEK EREDMÉNYEIRE
}

\author{
MEZŌ KATALIN ${ }^{1}$ - MEZŐ FERENC ${ }^{1}$ - SZABÓNÉ BALOGH ÁGOTA² \\ ${ }^{1}$ Debreceni Egyetem, Gyermeknevelési és Felnôttképzési Kar \\ ${ }^{2}$ Eszterházy Károly Egyetem, Pedagógiai Kar \\ E-mail: kata.mezo1@gmail.com
}

Beérkezett: 2016. november 24. - Elfogadva: 2017. április 23.

\begin{abstract}
Háttér és célkitúzések: a kreativitás idóbeliségével, például az idônyomás kreativitásra gyakorolt hatásával, kevés kutatás foglalkozik közvetlenül (Amabile, Mueller, Simpson, Hadley, Kramer és Fleming, 2002; Mainemelis, 2002), holott az idô szerepe számottevố a kreatív megnyilvánulások szempontjából. Jelen tanulmány célja, hogy rámutasson e téma fóbb kutatási területeire, és összefoglalja a tesztfelvételi idő kreativitásra gyakorolt hatásának vizsgálatával kapcsolatos eredményeket. Módszer: a kreativitás vizsgálatára a verbális Szokatlan használat teszt, illetve a figurális Körök teszt magyar adaptációját (Zétényi, 1989) alkalmaztuk $n=207$ középiskolás diák esetében. 10 perc/teszt tesztfelvételi idő állt rendelkezésre, melynek elsố felében fekete, második felében szines ceruzát használtak a válaszadók. Így lehetốvé vált a 0-5., az 5-10. és a 0-10. percben nyújtott fluencia, originalitás, flexibilitás, átlagos originalitás és relatív flexibilitás pontszám különbségeinek és kapcsolatainak kiszámítása. Az intelligenciát célzó kiegészítô vizsgálatként a Raven-féle SPM-tesztet alkalmaztuk. Eredmények: a tesztfelvételi idôtartamnak szignifikáns hatása van a kreativitás pontszámaira (pl. a vizsgálati személyek asszociációs múveleti sebessége idốvel csökken, s a tesztfelvétel elsố öt percében magasabb pontszámok születnek, mint a másodikban), és az intelligencia- és kreativitásteszt pontszámok közötti kapcsolat alakulására (a második félidôben tapasztalhatók korrelációk). A verbális és a figurális tesztek igen különböznek idóbeli aspektusaik tekintetében. Következtetések: tekintve, hogy a kreativitás tesztelése idókorláthoz kötött és tesztfüggố vizsgálat, a tesztfelvételi idôtartam megválasztása lényeges az eredmények alakulása és elemzése szempontjából.
\end{abstract}

Kulcsszavak: kreativitás, idô, intelligencia, teszt 


\section{BEVEZETÉS}

A kreativitás meghatározása nem egyszerú, mivel egységes, mindenki számára elfogadható kreativitásdefiníció még nem született (Wolf, 2014). Általános megegyezés van abban, hogy a kreativitás kétpólusú (Runco és Jaeger, 2012) azaz: kreatív egyrészt, ami eredeti, újszerú (Mönks és Ypenburg, 2011; Chen, Yien és Huang, 2011); másrészt ami hatékony, hasznos (Runco, 2004; de Bono, 2009). A legújabb értelmezésekben a kreativitás mint kulcskészség jelenik meg a „huszonegyedik századi készségek” (Binkley és mtsai, 2012) között. Más kutatók (Besançon, Lubart és Barbot, 2013; Barbot, Besançon és Lubart, 2015) pedig a kreativitást, az egyéni és társadalmi fejlôdést meghatározó emberi erőforrásként ismerik el.

A kreativitáskutatások igen széles körûek (ezek összefoglalásai megjelennek pl. Batey és Furnham, 2006; Kozbelt, Beghetto és Runco, 2010 csoportosításaiban). E kutatások között azonban ritkán foglalkoznak az idô kreativitásban betöltött szerepének direkt vizsgálatával, holott az alkotások létrejötte tekintetében kevés fontosabb faktor van, mint maga az idố (Runco, 1999).

\section{A kreativitás idóbeli aspektusai}

A következôkben a kreativitás vizsgálatára alkalmas, a Torrance Tests of Creative Thinking (TTCT - Torrance, 1966) néven ismert eljáráson, illetve ennek hazai adaptációján (Zétényi, 1989) keresztül mutatjuk be a kreativitástesztek temporális szempontból lényeges jellemzőit.

- A tartalmi validitás és az idô: idôvel változhat egy teszt tartalmi érvényességének megítélése arra vonatkozóan, hogy valójában mit is mérnek a hagyományosan kreativitásteszteknek nevezett eljárások (vö. Barkóczi, 2012). Kreativitástesztnek vagy divergens gondolkodást mérô tesztnek tekinthetôk-e inkább? Egyesek a divergens gondolkodást a kreativitás szinonimájának tekintik (vö. Silvia, Winterstein, Willse, Barona, Cram és Hess, 2008; Weiner, 2000), míg mások (Csíkszentmihályi, 1990; Runco, 2008) ez ellen érvelnek, mert nézópontjuk szerint a (nonkognitív személyiségvonásokat is magába foglaló) kreativitás több mint csupán kognitív képesség. Egyes korai kutatásokban az is felvetôdött, hogy a divergens gondolkodás elengedhetetlen része-e egyáltalán a kreativitásnak (Wallach, 1976): a véletlenek összjátékaként létrejövó alkotások esetében például a divergens gondolkodásnak nincs jelentôsége; $s$ a konvergens gondolkodás eredményeként létrejövố alkotásokban sem domináns a szerepe. Néhányan a kreativitás területspecifikus jellegére hívják fel a figyelmet (Runco, 2004; Silvia, Kaufman és Pretz, 2009).

- A konstrukciós validitás és az idô: érvényességi problémákat okozhat az idô-faktor a valós életbeli és a tesztfelvételi helyzetek összevetésekor. Lemons (2011) szerint a kreativitástesztek érvényességét megkérdôjelezi, hogy e tesztek nem veszik figyelembe az eredeti ötletek alkotásához szükséges idôt. Felmerül a kérdés, hogy a TTCT-jellegú (világosan definiált probléma fogalmi szintú megoldását néhány perc alatt megkívánó és a megoldások számát, eredetiségét és a flexibilis jellegét díjazó) teszthelyzet milyen kreativitást igényló élethelyzethez 
hasonlítható egyáltalán? A probléma az, hogy míg egy tesztben elég leírni az újszerú válaszokat egy adott ingerrel kapcsolatban, addig a valós életben sokszor összetett feladatok kreatív megoldására van szükség, nemcsak az „ötletelés”, hanem a megvalósítás síkján is, ami akár évekig is tarthat. Runco és Acar (2012), valamint Jauk, Benedek és Neubauer (2013) szerint is a teszteredmények inkább csak elốrejelzói a valós (életbeli) kreativitásnak, mintsem maga a kreativitás. Ugyanakkor a valós életben is akadnak olyan szituációk, munkakörök, amelyek a tipikus teszthelyzethez hasonló feltételek mellett követelnek meg kreatív teljesítményeket (Richards, 2010), például az időnyomás alatt dolgozó elsôsegélynyújtók, mérnökök esetében vagy állásinterjúk alkalmával. A tesztbeli kreativitáshoz hasonló szituációk köznevelési kontextusban is megjelenhetnek: Sternberg (2012) nagyszámú példát mutat be a legkülönbözóbb tantárgyakra vonatkozó kreatív feladatokkal kapcsolatban; Smith és Smith (2010) is utal az oktatás és a kreativitás kapcsolatára.

- A prediktív validitás és az idô: kérdésként merülhet fel, hogy a teszteredmények alapján bejósolhatók-e a késôbbi időpontban realizálódó jövôbeli teljesítmények. Kim (2007) szerint a TTCT prediktív validitása széles életkori skálán vizsgálva és hosszú idôtávon is jó, s Torrance (2002) is a prediktív validitásra utaló eredményeit alacsony, de megfeleló értékeknek tartotta. Azonban vannak olyan kutatások is, melyek a kreativitástesztek prediktív érvényességét megkérdőjelezik (Policastro és Gardner, 1999). Mások (Benedek, Borovnjak, Neubauer és KruseWeber, 2014) szerint nincs arra közvetlen bizonyíték, hogy a tesztekben jó eredményt elért személyek az életben is kreatívabbak.

- A diszkriminációs érvényesség és az idô: e két tényezô egymásra hatása jelenik meg Plucker (2000) vizsgálatában, melyben a diszkriminancia validitást igazolni látta ugyan (úgy találta, hogy a TTCT szubtesztjei közötti korrelációk magasabbak, mint a kreativitás- és intelligenciateszt közötti korrelációk), ám megjegyzi, hogy nem időnyomásos légkörben 0,1 körüli a tesztek közötti korreláció, idônyomásos teszthelyzetben 0,5 értékû korreláció is előfordulhat. A diszkriminációs validitással kapcsolatos problémák jelentkezése miatt a TTCT felépítése is változott az idôk során: a fluencia, originalitás és flexibilitás pontszámok közötti túl magas korrelációk miatt Torrance (1987) törölte a flexibilitást a pontozási rendszerbôl, mivel azok rontották a teszt diszkriminációs érvényességét. Megjegyzés: noha több kutató (Kim, 2006; Zétényi, 2010) is azt találta, hogy a kreativitástesztek jóformán csak a fluenciát mérik, Runco (2008) azonban arra figyelmeztet, hogy annak ellenére, hogy a fluencia, az originalitás és a flexibilitás pontszámok erôsen korrelálnak, mégis más és más információt nyújtanak a vizsgálati személyek kreatív potenciáljáról.

- A reliabilitás és az idô (pl. a teszt-reteszt megbízhatóság vizsgálatakor a két adatfelvétel közötti idô): a TTCT a reliabilitási vizsgálatokban megbízhatónak bizonyult, Kim (2006) és hazánkban Zétényi (1989) is kedvezô tapasztalatokról számolt be. Ugyanakkor lényeges kiemelni, hogy mivel a kreativitásjellemzók nem statikusak, a különbözó idôpontokban felvett kreativitástesztek eredményei is változhatnak idôvel. Emellett elvileg a hosszabb tesztfelvételi idô több megoldott feladatot/ választ eredményezhet. 
Mainemelis (2002) szerint, noha az idô a kognitív képességek - köztük a kreativitás - vizsgálatának egyik alapvetố faktora, mégis kevés szisztematikus vizsgálat látott napvilágot ezzel kapcsolatban. Még kevesebb az idônyomás kreativitásra gyakorolt hatásával foglalkozó kutatások száma (Amabile és mtsai, 2002), noha az alkotási folyamat és a kreatív eredmények fejlódésének megértése szempontjából meghatározó a rendelkezésre álló idô, az idônyomás befolyása (Baer és Oldham, 2006; Binnewies és Wörnlein, 2011); a munkafolyamatok sorrendisége vagy a szünetek hatása (Madjar és Shalley, 2008).

Ekwall (1983) szerint a kreativitás megjelenésének egyik alapja az elmélyüléshez szükséges idố biztosítása, ami lehetôséget teremt az elôzetesen nem tervezett folyamatok beiktatására, s a feladat megoldása során felmerülô új problémák végiggondolására. Idônyomás alatt azonban a rendelkezésre álló idố kerül középpontba, s ez nem feltétlenül azonos a (pl. inkubációhoz mint a kreatív folyamat egyik klasszikus eleméhez) szükséges idố mennyiségével (Wallas, 1926; Runco, 1999).

A nem teszthelyzetben történố kreativitásvizsgálatok az idônyomás kreatív teljesítményt korlátozó hatásáról számolnak be (Amabile és mtsai, 2002). Andrews és Smith (1996) negatív kapcsolatot talált az észlelt időhiány és a marketingötletek kreatív jellege között. Ugyanakkor Baer és Oldham (2006) megállapítja, hogy egy közepes erôsségú idônyomás érzése növeli a kreativitást, míg a szélsôségesen alacsonynak vagy magasnak észlelt idônyomás csökkenti.

A teszteket alkalmazó vizsgálatoknál is hasonló tapasztalatok jelentek meg: Hattie (1980) szerint az idôkorlát alkalmazásának vagy elvetésének hatása van a teszteredmények alakulására. Torrance (1969) is azt tapasztalta, hogy a kreativitástesztekben magasabb pontszámok jelennek meg, amikor a vizsgálati személyeknek 24 óra áll rendelkezésére, mint amikor csak 5 perc. Chase (1985) pedig azt vetette fel, hogy mivel a tesztfelvétel során létrehozott értékelhetô válaszok száma meghatározó a kreativitást célzó tesztek értékelése során, a lassú, megfontolt tempóban dolgozó vizsgálati személyek hátrányos helyzetbe kerülnek.

Beaty és Silvia (2012) a sorrendi hatás jelenségére hívják fel a figyelmet: a fluencia egy 10 perces tesztfelvételi helyzet elsố két percében a legmagasabb, majd gyorsan csökken - bár ez a csökkenés az intelligensebb személyek esetében mérsékeltebb. A fluencia csökken az idôvel, viszont az ötletek újdonságértéke, távoli asszociatív jellege egyre nô. Mindebbốl arra következtettek, hogy a végrehajtó folyamatok, különösen a stratégiák elốhívása és az ismeretekkel való manipulálás jól magyarázzák a sorrendi hatást, s az ötletek kreativitásának idôbeli lefutása függ a fluid intelligenciától. Megjegyzendô, hogy Chuderski (2015) a fluid intelligenciával és a munkamemóriával kapcsolatos vizsgálatában azt találta, hogy kapcsolatuk erôsebb a szúk idôkorláttal felvett tesztek esetében - feltételezhetô, hogy ez az intelligencia és a kreativitás esetében is így van. 


\section{VIZSGÁLAT}

A fentiek alapján célszerú foglalkozni a tesztfelvételi idôtartam kreativitásra gyakorolt hatásával, mivel általa a kreatív személyek azonosítása szempontjából meghatározó információkról (ötletgenerálás idóbelisége) kaphatunk képet; s erre irányuló hazai kutatási eredmények még nem állnak rendelkezésre (vö. Komlósi, 1975; Zétényi, 2010 vizsgálatait).

Jelen vizsgálatban arra kerestük a választ, hogy a tesztfelvételi idô hossza érdemben befolyásolja-e a kreativitástesztbeli eredményeket, vagy sem. Lényegesen különböznek-e a kreativitásmutatók egy összesen 10 perc idôtartamú tesztfelvétel elsô és második öt perce között? Várakozásunk szerint lényeges különbséget találunk a tesztfelvétel két félideje között egy-egy teszt kreativitás pontszámai tekintetében.

Másik kérdésünk arra vonatkozott, hogy vajon az elsô öt perc eredményei alapján prediktív jóslat tehetô-e a második öt perc eredményeit tekintve? Feltételezésünk szerint erôs korreláció tapasztalható a két félidő között.

Végül az intelligencia és a kreativitás idôszempontú kapcsolatát vizsgálva feltételeztük, hogy összességében mérsékelt kapcsolat lesz az intelligencia és a kreativitás között (vö. Plucker, 2000) a tesztfelvétel mindkét félidejében, valamint feltételeztük, hogy a magasabb intelligenciával jellemezhetô személyek minden tesztfelvételi idôintervallumban jobb eredményt érnek el a kreativitástesztekben.

\section{Minta}

A vizsgálatban 207 középiskolás (15-19 éves) korú tanuló vett részt 46,38\% (n = 96) fiú, 53,62\% ( $\mathrm{n}=111)$ lány. A Központi Statisztikai Hivatal rendelkezésre álló legutóbbi adatbázisa alapján Magyarország 15-19 éves korú népességében a férfi : nô százalékos arány $=51,23 \%: 48,77 \%$. A nemek aránya alapján súlyozott khi-négyzet próba eredménye szerint a nemek mintabeli eloszlása nem különbözik szignifikánsan az országos eloszlástól. A vizsgálatban való részvétel önkéntes és anonim, a szülôk által írásban engedélyezett volt.

\section{MÓDSZER}

A kreativitás vizsgálata érdekében a Szokatlan használat tesztet (Barkóczi és Klein, 1968; idézi Zétényi, 1989), illetve a Körök tesztet (Torrance, 1974; idézi Zétényi, 1989) vettük fel 10 perc/teszt megoldási idôt adva a vizsgálati személyeknek.

A tesztfelvételi idôtartam két felében keletkezett válaszok kontrollálásának módja: az adatfelvétel elókészítésekor fekete és színes (kék, piros) íróeszközt osztottunk ki a vizsgálati személyeknek. A tesztinstrukcióhoz (Zétényi, 1989) azt tettük hozzá, hogy az elsô öt percben fekete színnel kell majd dolgozni, majd jelzésre a színes ceruzával folytatandó a válaszadás. E színek alkalmazása révén lehetôség nyílt a két félidôbeli válaszok külön-külön történô figyelembevételére, és az egyéni teljesítmények értéke- 
lésére is. A kreativitástesztek értékelésekor a fluenciát, az originalitást, a flexibilitást, az átlagos originalitást és a relatív flexibilitást vettük figyelembe Zétényi (1989) alapján:

- Fluencia (F): kifejezésbeli könnyedség, mely az értékelhetô válaszok számával mérhetô. Magas értéke ötletgazdagságra utal.

- Originalitás $(\mathrm{O})$ : a válaszok szokatlanságát, eredetiségét, újszerúségét (tulajdonképpen: ritkaságát) méri. Magas értéke utal az eredeti, újszerú, szokatlan válaszok adására.

- Flexibilitás $(\mathrm{X})$ : azt mutatja, hogy hány különbözô kategóriába tartozó választ adott a vizsgálati személy. Magas érték rugalmas (nézôpontváltásra kész) gondolkodásra utal.

- Átlagos originalitás (ÁO = O/F): a mutató arra vonatkozóan ad támpontot, hogy az egyes válaszok originalitás értékei mekkorák a válaszok számától függetlenül. Magas értéke arra utal, hogy a személy válaszai egyenként is szokatlanok, eredetiek.

- Relatív flexibilitás $(\mathrm{RX}=\mathrm{X} / \mathrm{F})$ : a flexibilitás és a fluencia hányadosának magas értéke arra utal, hogy az egyén a válaszainak számához képest is többféle oldalról próbálta megközelíteni a feladatot, sokféle lehetôséget közölt.

Az értelmi képesség vizsgálatát a Raven-féle Standard Progressive Matricess (SPM - Raven, 1938; Szegedi, 1988) teszttel végeztük el, s értékelésekor az intelligenciahányadost vettük figyelembe. A tesztfelvételi idő 30 perc volt.

A tesztfelvételre normál középiskolai osztályokban került sor, a csoportok létszáma átlagosan 25-32 fó volt. A matematikai statisztikai elemzésben az SPSS és az R-nyelv szoftvereket alkalmaztuk - ezúton is köszönve Kurucz Gyôzó és Márton Sándor tanácsait.

\section{EREDMÉNYEK}

Az adatértékelés elsố lépéseként végzett Kolmogorov-Smirnov-próba eredménye szerint a változók döntô többsége nem normális eloszlást követett, így a továbbiakban nem paraméteres statisztikai próbák alkalmazása mellett döntöttünk.

A válaszok számát (a fluenciát) tekintve a Szokatlan használat teszt esetében a vizsgálati személyek által összesen adott 2218 db értékelhetô válasz 63,03\%-a (1398 válasz) érkezett a tesztfelvétel elsô öt percében. A Wilcoxon-féle elôjeles rangpróba szerint a félidôk közötti fluenciabeli különbség $\left(\mathrm{Me}_{1 \text {. félidố }}=6\right.$ és $\left.\mathrm{Me}_{2 \text {. félidốô }}=3\right)$ szignifikáns: $\mathrm{Z}=-8,633 ; \mathrm{p}<0,05$. A Körök teszt esetében a 3487 válasz körülbelül fele $(51,65 \%=1801$ válasz $)$ érkezett az elsô félidôben $\left(Z=-4,669 ; \mathrm{p}<0,05 ; \mathrm{Me}_{1 \text {. félidô }}=9\right.$ és $\left.\mathrm{Me}_{2 \text {. félidố }}=8\right)$.

Amikor az adatokat a vizsgálati személyek asszociációs múveleti sebessége (= válasz/ fô/perc) szempontjából elemeztük (ekkor a percenként jellemzô személyenkénti válaszok átlagos számát hasonlítottuk össze a tesztfelvétel két félideje között): a Wilcoxon-féle elôjeles rangpróba a Szokatlan használat teszt $\left(\mathrm{Me}_{0-5 \text {. perc }}=1,2 ; \mathrm{Me}_{5-10 \text {. perc }}=0,6\right.$; $\left.\mathrm{Me}_{0-10 \text {. perc }}=1,0 ; \mathrm{Z}=-8,633 ; \mathrm{p}<0,05\right)$ és a Körök teszt esetében $\left(\mathrm{Me}_{0-5 \text {. perc }}=1,8 ; \mathrm{Me}_{5-10 \text {. perc }}\right.$ $\left.=1,6 ; \mathrm{Me}_{0-10 \text {. perc }}=1,6 ; \mathrm{Z}=-4,669 ; \mathrm{p}<0,05\right)$ is gyorsabb asszociációs múveleti sebességet 


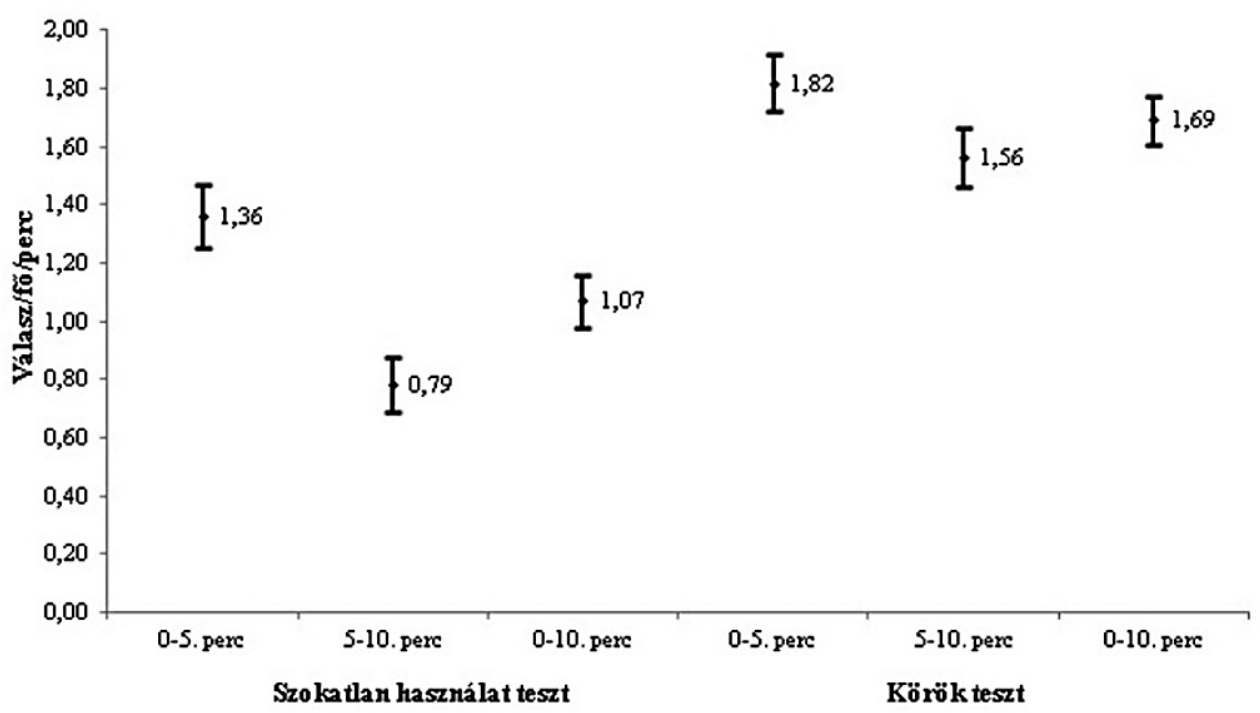

1. ábra. Percenkénti válaszok száma átlagosan

Megjegyzés: a számok átlagokat, a félszakaszok pedig a 95\%-os konfidencia intervallum alsó és felsố határait jelölik.

jelzett a tesztfelvétel 1 . félidejében. Érzékelhetô tehát, hogy mindkét tesztben nagyobb a válaszok létrehozásának átlagos tempója a tesztfelvétel elsô öt percében, viszont a különbség mégsem éri el az 1 válasz/perc értéket sem (1. ábra). Megjegyzendô azonban, hogy a Körök teszt mindkét félidejében szignifikánsan magasabb a percenként adott válaszok átlagos száma, mint a Szokatlan használat teszt bármelyik félideje esetében.

A tesztfelvételi idố kalibrálása szempontjából lényeges, hogy a vizsgálati személyek 74,5\%-ában az elsố, és csak 15,9\%-ában a második félidốben volt magasabb a Szokatlan használat teszt fluenciaértéke; míg 9,6\%-uk esetében azonos volt a két félidôbeli fluencia pontszám (khi-négyzet $=158,290 ; \mathrm{df}=2 ; \mathrm{p}<0,01$ ). A Körök tesztben az 1 . félidốben adott több választ a vizsgálati személyek $60,1 \%$-a, a 2 . félidốben adott több választ 30,8\%-uk; s azonos számú választ adott a személyek 9,1\%-a (khi-négyzet $=77,848$; $\mathrm{df}=2 ; \mathrm{p}<0,01)$.

A Wilcoxon-féle elójeles rangpróba szerint a Szokatlan használat teszt felvételének elsố öt percében nemcsak szignifikánsan $(\mathrm{p}<0,05)$ több, de eredetibb és flexibilisebb ötletek születtek, mint a második öt percben (1. táblázat).

A Körök teszt esetében heterogénebb eredményt kaptunk: noha a fluencia az elsô öt percben volt magasabb pontszámmal jellemezhetố, az átlagos originalitás és a relatív flexibilitás a második öt percben lett szignifikánsan $(\mathrm{p}<0,05)$ magasabb; míg az originalitás és a flexibilitás értéke nem különbözik szignifikánsan a két félidô között.

Arra is kerestük a választ, hogy a tesztfelvétel elsố felében (0-5. percében) nyújtott teljesítmény prediktív mutatója-e a második félidốben (vagyis az 5-10. percben) 
1. táblázat. A kreativitástesztek felvételének 0-5. és 5-10. percében nyújtott teljesítmények közötti különbségek

\begin{tabular}{|c|c|c|c|c|c|c|c|c|}
\hline \multirow{2}{*}{ Teszt } & \multirow{2}{*}{ Változó } & \multicolumn{3}{|c|}{ 0-5. percben } & \multicolumn{3}{|c|}{ 5-10. percben } & \multirow{2}{*}{$\mathrm{Z}$} \\
\hline & & Min. & Medián & Max. & Min. & Medián & Max. & \\
\hline \multirow{5}{*}{$\begin{array}{l}\text { Szokatlan } \\
\text { használat }\end{array}$} & Fluencia & 0,00 & 6,00 & 19,00 & 0,00 & 3,00 & 14,00 & $-8,633(\mathrm{a}) *$ \\
\hline & Originalitás & 0,00 & 2,94 & 9,36 & 0,00 & 1,66 & 9,12 & $-7,237(\mathrm{a})^{*}$ \\
\hline & Flexibilitás & 0,00 & 5,00 & 16,00 & 0,00 & 3,00 & 11,00 & $-7,866(\mathrm{a}) *$ \\
\hline & $\begin{array}{l}\text { Átlagos } \\
\text { originalitás }\end{array}$ & 0,08 & 0,46 & 0,93 & 0,00 & 0,42 & 0,86 & $-3,962(\mathrm{a}) *$ \\
\hline & $\begin{array}{l}\text { Relatív } \\
\text { flexibilitás }\end{array}$ & 0,50 & 0,90 & 1,00 & 0,00 & 0,88 & 1,00 & $-4,509(a) *$ \\
\hline \multirow{5}{*}{ Körök } & Fluencia & 1,00 & 9,00 & 20,00 & 0,00 & 8,00 & 25,00 & $-4,669(\mathrm{a}) *$ \\
\hline & Originalitás & 0,00 & 3,34 & 9,60 & 0,00 & 3,58 & 13,57 & $-1,435(\mathrm{~b})$ \\
\hline & Flexibilitás & 0,00 & 6,00 & 13,00 & 0,00 & 6,00 & 19,00 & $-1,667(\mathrm{a})$ \\
\hline & $\begin{array}{l}\text { Átlagos } \\
\text { originalitás }\end{array}$ & 0,00 & 0,39 & 0,61 & 0,00 & 0,49 & 0,82 & $-6,979(b) *$ \\
\hline & $\begin{array}{l}\text { Relatív } \\
\text { flexibilitás }\end{array}$ & 0,00 & 0,75 & 1,00 & 0,00 & 0,82 & 1,00 & $-3,769(b) *$ \\
\hline
\end{tabular}

a) 0-5. percbeli pontszám > 5-10. percbeli pontszám

b) $0-5$. percbeli pontszám $<5-10$. percbeli pontszám

*Wilcoxon-féle elôjeles rangpróba esetében $\mathrm{p}<0,05$

nyújtott teljesítménynek. A két félidôbeli pontszámok kapcsolatát Kendall-féle tau-b $\left(\tau_{\mathrm{b}}\right)$ monotonitási együttható kiszámításával vizsgáltuk. A Szokatlan használat teszt esetében a fluencia $\left(\tau_{\mathrm{b}}=0,35 ; 95 \% \mathrm{CI}=0,25-0,43\right)$, az originalitás $\left(\tau_{\mathrm{b}}=0,30 ; 95 \% \mathrm{CI}=\right.$ $0,20-0,38)$ és a flexibilitás $\left(\tau_{\mathrm{b}}=0,35 ; 95 \% \mathrm{CI}=0,25-0,43\right)$ tekintetében szignifikáns $(\mathrm{p}<0,05)$ kapcsolat található a tesztfelvétel két félideje között, míg az átlagos originalitás és a relatív flexibilitás két tesztfelvételi félidôben tapasztalt értékei közötti korreláció nem szignifikáns. A Körök teszt fluencia $\left(\tau_{\mathrm{b}}=0,30 ; 95 \% \mathrm{CI}=0,21-0,39\right)$, originalitás $\left(\tau_{\mathrm{b}}=0,21 ; 95 \% \mathrm{CI}=0,12-0,31\right)$, flexibilitás $\left(\tau_{\mathrm{b}}=0,13 ; 95 \% \mathrm{CI}=0,04-0,24\right)$ mutatói tekintetében szignifikáns $(\mathrm{p}<0,05)$ kapcsolat található a tesztfelvétel két félideje között, míg az átlagos originalitás és a relatív flexibilitás esetében nem.

A kreativitás és az intelligencia kapcsolatának vizsgálatakor a minta IQ alapján alsó $10 \%$-át trimmeltük, mivel (vélhetốleg motiválatlan tesztkitöltés miatt) extrém alacsony IQ értékek is tapasztalhatók voltak. Az így kapott minta leíró statisztikai adatai az IQ tekintetében: átlag $=102,20$; szórás $=10,79 ; \min .=76 ; \max .=126 ; 25$. percentilis $=$ 94,$50 ; 50$. percentilis $($ medián $)=103 ; 75$. percentilis $=110$.

Az IQ és kreativitás együttjárása tekintetében a Körök tesztben mindössze négy esetben találtunk szignifikáns, bár gyenge kapcsolatot a nonverbális intelligenciatesztben elért pontszámmal. Az említett $(\mathrm{p}<0,05)$ esetek: a tesztelés $5-10$. percében az IQ $\tau_{\mathrm{b}}=-0,09$ és $-0,12$ közötti gyenge, negatív irányú kapcsolatban áll a fluencia, az originalitás és a flexibilitás pontszámaival, illetve $\tau_{\mathrm{b}}=0,11$ kapcsolatban áll a relatív flexibilitás pontszámával. A verbális Szokatlan használat teszt esetében pedig a tesztelés 5-10. percbeli félidejében és teljes 10 perces idôtartamát tekintve is több gyenge $\left(\tau_{\mathrm{b}}=0,11-0,23\right.$ körüli, $\left.\mathrm{p}<0,05\right)$ kapcsolat figyelhetô meg az IQ és a kreativitásváltozók között (2. táblázat). 
2. táblázat. A Szokatlan használat teszt felvételének 0-5. és 5-10., valamint 0-10. percében nyújtott teljesítmények Kendall-féle tau-b monotonitási együttható $\left(\tau_{\mathrm{b}}\right)$ révén mért kapcsolata az SPM intelligenciatesztben elért IQ-ponttal

\begin{tabular}{|c|c|c|c|c|}
\hline \multirow{2}{*}{\multicolumn{2}{|c|}{ Változó }} & \multicolumn{3}{|c|}{ Szokatlan használat teszt } \\
\hline & & \multirow{2}{*}{$\begin{array}{r}0-5 \text {. perc } \\
0,11 \\
-0,02-0,21\end{array}$} & \multirow{2}{*}{$\begin{array}{r}5-10 . \text { perc } \\
0,12^{*} \\
0,02-0,22 \\
\end{array}$} & \multirow{2}{*}{$\begin{array}{r}-10 . \text { perc } \\
0,12^{*} \\
0,00-0,23 \\
\end{array}$} \\
\hline Fluencia & $\begin{array}{l}\tau_{\mathrm{b}:} \\
\mathbf{9 5 \%} \mathrm{CI}:\end{array}$ & & & \\
\hline Originalitás & \begin{tabular}{|l|}
$\tau_{\mathrm{b}:}$ \\
$\mathbf{9 5 \%} \mathbf{C I}:$
\end{tabular} & $\begin{array}{r}0,10 \\
-0,02-0,20\end{array}$ & $\begin{array}{r}0,12 * \\
0,02-0,22\end{array}$ & $\begin{array}{r}0,11 * \\
0,02-0,22\end{array}$ \\
\hline Flexibilitás & \begin{tabular}{|l|}
$\tau_{\mathrm{b}:}$ \\
$\mathbf{9 5 \%} \mathbf{C I}:$
\end{tabular} & $\begin{array}{r}0,13^{*} \\
-0,01-0,24\end{array}$ & $\begin{array}{r}0,14^{*} \\
0,03-0,24\end{array}$ & $\begin{array}{r}0,14^{*} \\
0,04-0,25\end{array}$ \\
\hline Átlagos originalitás & \begin{tabular}{|l|}
$\tau_{\mathrm{b}:}$ \\
$\mathbf{9 5 \%} \mathrm{CI}:$
\end{tabular} & $\begin{array}{r}0,05 \\
-0,04-0,13 \\
\end{array}$ & $\begin{array}{r}0,18^{*} \\
0,07-0,27\end{array}$ & $\begin{array}{r}0,17 * \\
0,08-0,27\end{array}$ \\
\hline Relatív flexibilitás & \begin{tabular}{|l|}
$\tau_{\mathrm{b}:}$ \\
$\mathbf{9 5 \%} \mathbf{C I}:$
\end{tabular} & $\begin{array}{r}0,02 \\
-0,06-0,12\end{array}$ & $\begin{array}{r}0,23^{*} \\
0,12-0,32\end{array}$ & $\begin{array}{r}0,20 * \\
0,10-0,28\end{array}$ \\
\hline
\end{tabular}

$* \mathrm{p} \leq 0,05$

További adatelemzés céljából az IQ alapján magas pontszámú (a 75. percentilis feletti, 110-126 IQ) és alacsony pontszámú (a 25. percentilis alatti, 75-95 IQ) csoportokat hoztunk létre, s Mann-Whitney-féle U-próba révén hasonlítottuk össze különbözô idôintervallumokban elért kreativitástesztbeli teljesítményeiket. A Szokatlan használat teszt esetében a magasabb IQ-val jellemezhetô csoport szignifikánsan jobb eredményt ért el (3. táblázat).

3. táblázat. A Szokatlan használat teszt felvételének 0-5. és 5-10., valamint 0-10. percében nyújtott teljesítménybeli különbség a 75-95 IQ,

illetve a 110-126 IQ-pontot elérô csoportok között

\begin{tabular}{llcccc}
\hline $\begin{array}{l}\text { Tesztfelvételi } \\
\text { idó }\end{array}$ & \multicolumn{1}{c}{ Változó } & $\begin{array}{c}\text { Csoport: } \\
\mathbf{7 5 - 9 5} \text { IQ } \\
\text { (medián) }\end{array}$ & $\begin{array}{c}\text { Csoport: } \\
\mathbf{1 1 0 - 1 2 6} \text { IQ } \\
\text { (medián) }\end{array}$ & U & Z \\
\hline 0-5. perc & Fluencia & 6,00 & $<7,00$ & 912,50 & $-1,748$ \\
& Originalitás & 2,39 & $<3,19$ & 904,50 & $-1,801$ \\
& Flexibilitás & 5,00 & $<6,00$ & 834,50 & $-2,329^{*}$ \\
& Átlagos originalitás & 0,42 & $<0,46$ & 892,50 & $-1,573$ \\
& Relatív flexibilitás & 0,87 & $<0,90$ & 1048,50 & $-0,409$ \\
\hline 5-10. perc & Fluencia & 2,00 & $<3,00$ & 783,50 & $-2,710^{*}$ \\
& Originalitás & 0,70 & $<1,89$ & 770,50 & $-2,794^{*}$ \\
& Flexibilitás & 2,00 & $<3,00$ & 759,50 & $-2,890^{*}$ \\
& Átlagos originalitás & 0,32 & $<0,48$ & 706,50 & $-3,266^{*}$ \\
& Relatív flexibilitás & 0,50 & $<1,00$ & 706,00 & $-3,427^{*}$ \\
\hline 0-10. perc & Fluencia & 8,50 & $<10,00$ & 865,50 & $-2,090^{*}$ \\
& Originalitás & 3,69 & $<5,08$ & 844,50 & $-2,241^{*}$ \\
& Flexibilitás & 7,00 & $<9,50$ & 797,00 & $-2,597^{*}$ \\
& Átlagos originalitás & 0,35 & $<0,47$ & 677,00 & $-3,471^{*}$ \\
& Relatív flexibilitás & 0,67 & $<0,90$ & 692,50 & $-3,369^{*}$ \\
\hline
\end{tabular}

*Mann-Whitney-féle U-próba esetében p $\leq 0,05$ 
A Körök teszt esetében nincs különbség az IQ alapján szervezett csoportok teljesítményében a tesztfelvétel egyik idôintervallumában sem.

A Szokatlan használat teszt esetében a tesztfelvétel két félideje közötti $(p<0,05)$ kapcsolatok vizsgálatakor az alacsonyabb és magasabb IQ pontszámbeli csoportban is csak a fluencia $\left(\tau_{\mathrm{b}}=0,28\right.$ és 0,30$)$, az originalitás $\left(\tau_{\mathrm{b}}=0,23\right.$ és 0,23$)$ és a flexibilitás $\left(\tau_{\mathrm{b}}=\right.$ $0,32$ és 0,23$)$ mutatott mérsékelt együttjárást. Az átlagos originalitást tekintve a magasabb IQ-val jellemezhetô csoportban $\tau_{\mathrm{b}}=-0,20$ kapcsolat volt tapasztalható.

A Körök teszt esetében sem az alacsony, sem a magas IQ pontszámot eléróknél nem tapasztaltunk szignifikáns $(\mathrm{p}<0,05)$ kapcsolatot a két félidố között.

\section{DISZKUSSZIÓ}

Tanulmányunk célja a tesztfelvételi idô kreativitásra gyakorolt hatásának vizsgálata volt. Úgy tûnik, hogy a tesztfelvételi idônek hatása van a kreativitásmutatókra (különösen a fluenciára) és az azok közötti korrelációs kapcsolatokra, mely kapcsolatok alakulásában a vizsgálati személyek intelligenciájának is van némi szerepe.

A kreativitás vizsgálatába bevont változók nem normális eloszlást követtek - ez Piirto (2004) és Plucker (2000) tapasztalatait támasztja alá, s kizárta a normális eloszlást feltételezó paraméteres statisztikai eljárások alkalmazását az adatelemzésból.

A tesztfelvétel két félideje közötti pontszámok különbségére vonatkozó hipotézisünk megerôsítést nyert. Eredményeink szerint - melyek alátámasztják Beaty és Silvia (2012) sorrendi hatásra vonatkozó tapasztalatait - a kreativitásmutatók (fóként a verbális teszt esetében) különböznek egy 10 perc idôtartamú tesztfelvétel 1. és 2. öt perce között; az ötletgenerálás nem oszlik el egyenletesen a tesztfelvétel két félideje között. E különbség jellege azonban tesztspecifikus - kivéve a fluencia pontszámot. A verbális és a figurális tesztek a (vizsgált kreativitásváltozók között a legobjektívebben pontozható, s egyetlen mennyiségi mutatónak tekinthetô) fluencia terén hasonlítanak egymásra abból a szempontból, hogy a tesztfelvétel elsô öt perces szakaszában szignifikánsan több választ adnak a vizsgálati személyek (tehát asszociációs múveleti sebességük is gyorsabb), mint a második öt perces terminusban. A válaszszám csökkenése egyrészt az ötletgenerálással összefüggô kognitív funkcióbeli (Silvia, Beaty és Nusbaum, 2013), másrészt stratégiabeli okokkal magyarázható (Gilhooly, Fioratou, Anthony és Wynn, 2007).

A Chase (1985) által felvetett aggodalom, hogy az időnyomásos teszthelyzet nem kedvez a lassabb tempóban dolgozóknak, vizsgálati személyeink kb. 25\%-ában bizonyult megalapozottnak a verbális és $40 \%$-ában a figurális tesztek esetében, számukra a hosszabb tesztfelvételi idô a kedvezôbb. A többiek jellemzôen a tesztfelvétel elsô félidejében adtak nemcsak több, de eredetibb és rugalmasabb gondolkodást tükrözô választ. Mindez azt is jelenti, hogy a kreatívabbnak tekinthetô személyek gyorsabban képesek a kreatív potenciálok mozgósítására.

A két tesztfelvételi idôben elért pontszámok közötti erôs monoton kapcsolatra vonatkozó hipotézisünk nem nyert alátámasztást. Eredményeink szerint legfeljebb mérsékelt szintú $\left(\tau_{\mathrm{b}}=0,3\right.$ körüli) kapcsolat tapasztalható a 10 perces tesztfelvételi intervallum két félideje között. A predikció szempontjából ez meglehetôsen gyenge eredmény 
- az elsô félidô eredménye alapján a második félidô eredménye nem jósolható meg megnyugtató módon.

Az intelligencia és kreativitás mérsékelt kapcsolatára vonatkozó feltevéseink nem nyertek megerôsítést - bár a verbális kreativitás teszt esetében gyenge kapcsolatokat tapasztalhattunk. Úgy tûnik, hogy a kreativitás verbális tesztjében némi elônyt jelent az intelligencia magasabb foka - ez azonban kevésbé jellemzô a figurális teszt esetében.

Tovább vizsgálva a mintabeli alacsony/magas IQ pontokkal jellemezhetô csoportok közötti fốbb különbségeket, megállapítható, hogy: a) a magas intellektusú csoport a verbális kreativitástesztben magasabb pontszámokat ért el a tesztelés 2. felében és teljes intervallumában; b) a figurális kreativitásteszt esetében az alacsony és a magas intellektusú csoport kreativitásmutatói között nincs különbség. Tehát a figurális kreativitás teszt alkalmazása jobban kompenzálja az intellektuális különbségeket, mint a verbális kreativitásteszt. Ennek tudatosítása kiemelkedóen fontos például a különbözó szociális és kulturális hátterú csoportok tehetségvizsgálata során.

\section{KÖVETKEZTETÉSEK}

Kutatási tapasztalataink alátámasztják, hogy a tesztfelvételi idô hatással van a kreativitásra. Valószínúsíthetôen azok a személyek lesznek kreatívabbak az iskolában, az egyetemen vagy a munkahelyen, akik képesek jobb eredmények elérésére egy rövidebb idôintervallumú, nagyobb idônyomást alkalmazó, s így rövidebb inkubációs periódust engedélyezô tesztfelvétel idején. A kutatásunkban tapasztalt tesztek közötti különbségek alátámasztják Runco (2004) felvetését arról, hogy a kreativitás téma- és feladatspecifikus jellegú; s ezt célszerú figyelembe venni a kreativitást célzó kutatásokban. Emellett a kreativitás tekintetében a tesztfelvételi időintervallum megfelelô megválasztása is befolyásoló, így a hazánkban használatban lévő, revideálásra megérett (25 éve nem frissített) kreativitástesztek értékelési rendszerének megalkotása során szükséges a tesztfelvételi idó újragondolása is.

\section{IRODALOM}

Amabile, T. M., Mueller, J. S., Simpson, B. S., Hadley, C. N., Kramer, S. J., \& Fleming, L. (2002). Time Pressure And Creativity In Organizations: A Longitudinal Field Study. Harvard Business School Working Paper, No. 02-073.

Andrews, J., \& Smith, D. C. (1996). In search of the marketing imagination: Factors affecting the creativity of marketing programs for mature products. Journal of Marketing Research, 33, 174-187.

Baer, M., \& Oldham, G. R. (2006). The Curvilinear Relation Between Experienced Creative Time Pressure and Creativity: Moderating Effects of Openness to Experience and Support for Creativity. Journal of Applied Psychology, 91(4), 963-970.

Barbot, B., Besançon, M., \& Lubart, T. (2015). Creative potential in educational settings: its nature, measure, and nurture. Education, 3-13.

Barkóczi I. (2012). A pozitív pszichológia és a kreativitás kapcsolata. Magyar Pszichológiai Szemle, 67(1), 173-181. 
Barkóczi I., \& Klein S. (1968). Gondolatok az alkotóképességrôl és vizsgálatának problémáiról. Magyar Pszichológiai Szemle, 25, 508-515.

Batey, M., \& Furnham, A. (2006). Creativity, intelligence, and personality: a critical review of the scattered literature. Genetic, Social, and General Psychology Monographs, 132(4), 355-429.

Beaty, R. E., \& Silvia, P. J. (2012). Why Do Ideas Get More Creative Across Time? An Executive Interpretation of the Serial Order Effect in Divergent Thinking Tasks. Psychology of Aethetics Creativity and the Arts, 6(4), 309-319.

Benedek, M., Borovnjak, B., Neubauer, A. C., \& Kruse-Weber, S. (2014). Creativity and personality in classical, jazz and folk musicians. Personality and Individual Differences, 63, 117-121.

Besançon, M., Lubart, T. I., \& Barbot, B. (2013). Creative giftedness and educational opportunities. Educational and Child Psychology, 30(2), 79-88.

Binkley, M., Erstad, O., Herman, J., Raizen, S., Ripley, M., Miller-Ricci, M., \& Rumble, M. (2012). Defining Twenty-First Century Skills. In P. Griffin, B. McGaw, E. Care (eds), Assessment and Teaching of 21st Century Skills (17-66). Dordrecht: Springer.

Binnewies, C., \& Wörnlein, S. C. (2011). What makes a creative day? A diary study on the interplay between affect, job stressors, and job control. Journal of Organizational Behavior, 32, 589-607.

de Bono, E. (2009). A kreatív elme. Budapest: HVG Kiadó.

Chase, C. (1985). Review of the Torrance test of creative thinking. In J. Mitchell (ed.), The Ninth Mental Measurement Yearbook (1631-1632). Lincoln: University of Nebraska Press.

Chen, K. H., Yien, J. M., \& Huang, C. J. (2011). The Perceived Leader Support Behavior for Sub-ordinate's Creativity: The Moderating Effect of Trust. Journal of Social Sciences, 7(2), 257-264.

Chuderski, A. (2015). The broad factor of working memory is virtually isomorphic to fluid intelligence tested under time pressure. Personality and Individual Differences, 85, 98-104.

Csíkszentmihályi, M. (1990). Motiváció és kreativitás: út a megismerés strukturális, illetve energetikai megközelítésének szintézise felé. Pszichológia, 10(1), 3-25.

Ekvall, G. (1983). Climate, structure and innovativeness of organizations: a theoretical framework and an experiment. Report 1. FA radet, The Swedish Council for Management and Organizational Behaviour, Stockholm.

Gilhooly, K. J., Fioratou, E., Anthony, S. H., \& Wynn, V. (2007). Divergent thinking: Strategies and executive involvement in generating novel uses for familiar objects. British Journal of Psychology, 98, 611-625.

Hattie, J. (1980). Should creativity tests be administered under test-like conditions? An empirical study of three alternative conditions. Journal of Educational Psychology, 72, 87-98.

Jauk, E., Benedek, M., \& Neubauer, A. C. (2013). The Road to Creative Achievement: A Latent Variable Model of Ability and Personality Predictors. European Journal of Personality, 28(1), 95-105.

Kim, K. H. (2006). Can we trust creativity tests? A review of the Torrance Tests of Creative Thinking (TTCT). Creativity Research Journal, 18, 3-14.

Kim, K. H. (2007). The Two Torrance Creativity Tests: The Torrance Tests of Creative Thinking and Thinking Creatively in Action and Movement. In Al-Girl Tan (ed.), Creativity. A Handbook for Teachers (117-141). London: World Scientific Publishing.

Komlósi A. (1975). Kreativitás és percepció. Magyar Pszichológiai Szemle, 32, 409-418.

Kozbelt, A., Beghetto, R. A., \& Runco, M. A. (2010). Theories of creativity. In J. C. Kaufman, R. J. Sternberg (eds). Cambridge Handbook of Creativity (20-47). New York: Cambridge University Press.

Lemons, G. (2011). Diverse Perspectives of Creativity Testing: Controversial Issues When Used for Inclusion Into Gifted Programs. Journal for the Education of the Gifted, 34(5), 742-772. 
Madjar, N., \& Shalley, C. E. (2008). 'Multiple Tasks' and 'Multiple Goals' Effect on Creativity: Forced Incubation or Just a Distraction? Journal of Management, 34(4), 786-805.

Mainemelis, C. (2002). Time and Timelessness: Creativity in (and out of) the Temporal Dimension. Creativity Research Journal, 14(2), 227-238.

Mönks, J. F., \& Ypenburg, H. I. (2011). Ha tehetséges a gyermek. Budapest: Magyar Tehetségsegítô Szervezetek Szövetsége.

Piirto, J. (2004). Understanding Creativity. Scottsdale: Great Potential Press.

Plucker, J. A. (2000). Is the proof in the pudding? Reanalyses of Torrance's (1958 to present) longitudinal data. Creativity Research Journal, 12, 103-114.

Policastro, E., Gardner, H. (1999). From case studies to robust generalizations: An approach to the study of creativity (213-225). In R. Sternberg (ed.), Handbook of Creativity. New York: Cambridge University Press.

Raven, J. C. (1938). Progressive Matrices Guide to Using Matrices. London: University of London.

Richards, R. (2010). Everyday creativity: process and way of life four - key issues (189-215). In: J. C. Kaufman, R. J. Sternberg (eds), Cambridge Handbook of Creativity. New York: Cambridge University Press.

Runco, M. A. (1999). Time (659-663). In M. A. Runco, S. Pritzker (eds), Encyclopedia of Creativity. (Vol. 2). San Diego, CA: Academic.

Runco, M. A. (2004). Creativity. Annual Review of Psychology, 55, 657-687.

Runco, M. A. (2008). Commentary: Divergent Thinking Is Not Synonymous With Creativity. Psychology of Aesthetics, Creativity, and the Arts, 2, 93-96.

Runco, M. A., \& Acar, S. (2012). Divergent Thinking as an Indicator of Creative Potential. Creativity Research Journal, 24(1), 66-75.

Runco, M. A., \& Jaeger, G. J. (2012). The Standard Definition of Creativity. Creativity Research Journal, 24(1), 92-96.

Silvia, P. J., Beaty, R. E., \& Nusbaum E. C. (2013). Verbal fluency and creativity: General and specific contributions of broad retrival ability (Gr) factors to divergent thinking. Intelligence, 41, 328-340.

Silvia, P. J., Kaufman, J. C., Pretz, J. E. (2009). Is Creativity Domain-Specific? Latent Class Models of Creative Accomplishments and Creative Self-Descriptions. Pscychology of Aesthetics, Creativity, and the Arts, 3, 139-148.

Smith, J. K., \& Smith, L. F. (2010). Educational creativity (250-264). In J. C. Kaufman, R. J. Sternberg (eds), Cambridge Handbook of Creativity. New York: Cambridge University Press.

Sternberg, R. J. (2012). The Assessment of Creativity: An Investment-Based Approach. Creativity Research Journal, 24(1), 3-12.

Silvia, P. J., Winterstein, B. P., Willse, J. T., Barona, C. M., Cram, J. T., \& Hess, K. I. (2008). Assessing creativity with divergent thinking tasks: Exploring the reliability and validity of new subjective scoring methods. Psychology of Aesthetics, Creativity, and the Arts, 2, 68-85.

Szegedi M. (1988). Raven-féle intelligenciavizsgáló eljárás (124-135). In Mérei F., Szakács F. (szerk.), Pszichodiagnosztikai Vademecum III. Budapest: Tankönyvkiadó.

Torrance, E. P. (1966). Torrance Tests of Creative Thinking: Norms-technical Manual. Princeton: Personnel Press.

Torrance, E. P. (1969). Curiosity of gifted children and performances on timed and untimed tests of creativity. Gifted Child Quarterly, 13, 155-158.

Torrance, E. P. (1974). The Torrance Tests of Creative Thinking-Norms-Technical Manual Research Edition-Verbal Tests, Forms A and B Figural Tests, Forms A and B. Princeton, NJ: Personnel Press.

Torrance, E. P. (1987). Guidelines for Administration and Scoring/comments on Using the Torrance Tests of Creative Thinking. Bensenville, IL: Scholastic Testing Service Inc. 
Torrance, E. P. (2002). The Manifesto: A Guide to Developing a Creative Career. Westport, CT: Ablex.

Wallach, M. (1976). Tests tell us little about talent. American Scientist, 64, 57-63.

Wallas, G. (1926). The Art of Thought. New York: Harcourt Brace.

Weiner, R. (2000). Creativity and Beyond: Cultures, Values, and Change. Albany: State University of New York Press.

Wolf, R. N. (2014). Defining the Concept of Creativity. Enschede: University of Twente.

Zétényi, T. (1989). A kreativitás-tesztek tesztkönyve I-II. Budapest: Munkalélektani Koordináló Tanács.

Zétényi, T. (2010). A kreativitás pszichometriája és a gondolkodás. Magyar Pszichológiai Szemle, 65(2), 233-242.

\title{
THE EFFECT OF TESTING TIME ON THE RESULTS OF CREATIVITY TESTING
}

\author{
MEZŐ, KATALIN - MEZÖ, FERENC - SZABÓNÉ BALOGH, ÁGOTA
}

Background and aims: relatively few research focuses directly on the temporal properties (e.g. effect of time pressure) of creativity (Amabile Mueller, Simpson, Hadley, Kramer E Fleming, 2002; Mainemelis, 2002), although the role of time is considerable in terms of creative manifestations. The aim of this study is to introduce the main research areas related to this topic and summarize the results of studies on the effect of testing time on creativity. Methods: the Hungarian adaptation of the verbal Unusual Uses Test and the figural Circles Test (Zétényi, 1989) were applied to measure creativity at $n=207$ secondary school students. Testing time for giving answers was 10 minutes/test. In the first half of the testing time subjects used black pencils while in the second half of testing time they used coloured pencils. As a result, it was possible to calculate the scores of fluency, originality, flexibility, average originality and relative flexibility in the 0-5. min, 5-10. min and 0-10. min time intervals. As a supplementary examination, the intelligence was tested by Raven's SPM test. Results: the testing time-interval has significant effect on the scores of creativity (e.g. the subjects' associational processing speed decreases, the scores are higher in the first half of the testing time than in the second half), and the connection between scores of intelligence and creativity tests (correlations are observable only in the second half of the testing time). The verbal and figural tests differ from each other in terms of their timing aspects. Discussion: Considering that testing of creativity is a time limited and test-dependent examination, the choice of testing time is crucial from the perspective of the results' and their analysis.

Keywords: creativity, time, intelligence, test 